Surkhet

\title{
Role of the Literature in ELT Course of Mid-Western University
}

\author{
- Resham Bahadur Bist
}

\begin{abstract}
This article identifies the role of literature course included in B.Ed. English Curriculum of Mid-Western University for the promotion of language skills and areas. It begins with the general introduction of literary course either it supports to EFL/ESL context. The research questions and objectives are set to examine the role of literature course in ELT classroom. Then it is closely observed literature contents in B.Ed. English curriculum. It is discussed via self-inspection and reflection of my own experience. It reaches in conclusion that literary texts provide rich linguistic input and effective stimuli for students to express themselves, and a potential source of learner motivation. These texts also provide an opportunity for multi-sensorial classroom experiences and can appeal to learners with different learning style. The students can promote their creativity and language proficiency in ESL/EFL context of ELT classroom. Therefore, it is essential to design the literary texts in ELT course to promote both the language skills (i.e. listening, speaking, reading, and writing) and language areas (i.e. vocabulary, grammar, and pronunciations).
\end{abstract}

Key words: Literature, Literary texts, Curriculum, Language, and B.Ed. English

\section{Introduction}

"In literary texts, language is often there to be looked at as well as through (it is like stained glass in churches rather than plate glass in offices)".

- Peter Falvey \& Peter Kennedy (2006: IV)

Regarding the role of literature courses in ELT classroom, there are two different positions, namely essentialist and non-essentialist. The scholars who are under the essentialist position argue that studying literature may not help the development of second language competence and proficiency in the EFL context (Edmondson, 1997). Likewise this non-essentialist position 
regards no or limited value of using literature in language teaching and argues that "it is not essential to handle literature in the interest of developing adequate L2... proficiency (...) and literary texts have no essence that distinguishes them from other type of texts" (Yuksel; 2007, p. 45).

On the other hand, an essentialist position supports the argument that the study of literature can facilitate the development of language, aware to the learners about the cultural, promote the students' critical thinking, and their motivation in a foreign language classroom. There is a growing body of books, chapters, and articles about the value of literature in foreign language teaching programs (Tehan, Yuksel \& Inan; 2015, p. 2). In the 1980s, a lot of research was conducted with a view to identifying the role of literary texts in the language classrooms (Collie \& Slater, 1987; Johnson, 1981; Widdowson, 1983). Some practitioners believe that literary texts should be used for language teaching purposes for a number of reasons. Lazar (1993) has stated that literature should be useful in the language classroom because of the following reasons:

- It is very motivating.

- It is authentic material.

- It has general educational value.

- It is found in many syllabuses.

- It helps students to understand another culture.

- It is a stimulus for language acquisition.

- It develops students' interpretative abilities.

- Students enjoy it and it is fun.

- It is highly valued and has a high status.

- It expands students' language awareness.

- It encourages students to talk about their opinions and feelings.

The four-year B.Ed. English curriculum of Mid-Western University has consisted forty-five papers during the whole eight semesters. The focus of the curriculum is on English education and its different dimensions. It has also introduced course of literature to promote the proficiency of English language, promotion of critical thinking and creative writing and develop reading skills in EFL classroom since its establishment. Generally, in the B.Ed. English curriculum, English literature is seen to play two roles; i.e. literature as a study and literature as a resource of learning different dimension of language. The literature course highlights literature as a resource paradigm where literature is seen as a tool and resource to promote English language learning. This role of literature as an avenue to improve English proficiency has often been highlighted in the B.Ed. English curriculum in Mid-Western University. 


\section{Research Questions}

For identifying the role of literature course in the ELT Class, the following research questions were formulated:

- What is the role of literature course in the B.Ed. English curriculum for the proficiency of English language?

- How does literature course support the personal enrichment of students?

- Does literature course support the creativity of ELT students?

\section{Objectives}

The main objective of this study was to identify the role of literary texts in B. Ed. English curriculum in Mid-Western University. Beside this, specifically the study seeked to:

- Identify the literature course introduced in the ELT curriculum in EFL context;

- Examine the role of literary texts in B.Ed. English Curriculum;

- Find out the relevance of literature in the promotion of language skills.

\section{Methods}

This short article has purely based on the qualitative research approach; therefore, I had closely read and re-read the journal articles and textbooks related to the literature in ELT classroom and B.Ed. English curriculum. I had also prepared it via self-inspection and reflection of own experience and reached in conclusion through discursive validation.

\section{Place of Literature in B.Ed. English Curriculum}

The curriculum of B.Ed. English has outlined for the enhancement of English language proficiency and personal enrichment among the bachelor's level students. The course has aimed to make students enable in learning and teaching English language. In this curriculum, literary texts are also prescribed for the development of English language.

Table No. 1: Number of Literary Texts Used in B.Ed. English Curriculum

\begin{tabular}{|l|l|l|l|}
\hline Semester & \multicolumn{1}{|c|}{ Drama } & \multicolumn{1}{c|}{ Novel/ Short Stories } & \multicolumn{1}{c|}{ Poetry } \\
\hline Second & & $\begin{array}{l}\text { Course Title: Fiction Study } \\
\text { (Eng: 325) No. of Novels/ } \\
\text { Short Stories- 6/22 }\end{array}$ & \\
\hline Fourth & & & $\begin{array}{l}\text { Course Title: Poetry Study } \\
\text { (Eng. 345) No. of Poems-130 }\end{array}$ \\
\hline Sixth & $\begin{array}{l}\text { Course Title: Drama Study } \\
\text { (Eng: 365) No. of Dramas-7 }\end{array}$ & & \\
\hline
\end{tabular}

Source: Bachelor in English Education Course, Mid-Western University 2013 
The three fold genres of literature; fiction, poetry, and drama are prescribed in second, fourth and sixth semester respectively. There are 130 poems composed by prominent English poets in fourth semesters course entitled "Poetry Study". Those prescribed poems are categorized under the different themes. Likewise, 6 novels and 22 short stories are in the second semester written by written by English and Non-English authors entitled "Fiction Study". There is another literature course in sixth semester entitled "Drama Study" that consists 7 famous English dramas. Students are generally given exposure to the literature components too along with the study of genres of literature. Different texts are used in the various forms. These texts are a mix of local as well non-local literary texts. After the study of these different genres of literature, students can develop their personal feeling, opinion, and experiences. Likewise, they know about the different functions of language after the aesthetic judgment of literary texts. The number of prescribed literary texts are shown in Table 1. The assessment for the English literature component includes multiple choice questions as well as short and long questions for the end semester exam.

Table No. 2: Objectives of Literature Course

\begin{tabular}{|c|c|c|}
\hline Semester & Course Title & Objectiv \\
\hline Second & $\begin{array}{l}\text { Fiction Study } \\
\text { (Eng:325) }\end{array}$ & $\begin{array}{l}\text { - To acquaint the students with different elements of fiction. } \\
\text { - To help them enjoy reading short stories as well as develop reading } \\
\text { skills in them. } \\
\text { - To expose the students to different novels. } \\
\text { - To enable them to teach novels in the classroom. }\end{array}$ \\
\hline Fourth & $\begin{array}{l}\text { Creative Writing } \\
\text { Seminar } \\
\text { (Eng: } 343)\end{array}$ & $\begin{array}{l}\text { - To expose students to a wide range of verse forms and structures } \\
\text { and the components of short story } \\
\text { - To engage them in the experience techniques that can be used to use } \\
\text { creative writing in ELT } \\
\text { - To help students gain confidence in writing in a wide range of verse } \\
\text { forms } \\
\text { - To show in students an ability to recognize and experiment with } \\
\text { different poetic structures and techniques } \\
\text { - To help them gain confidence in writing short stories } \\
\text { To develop in students an ability to engage their students in creative } \\
\text { writing activities to improve their English. }\end{array}$ \\
\hline Fourth & $\begin{array}{l}\text { Poetry Study } \\
\text { (Eng:345) }\end{array}$ & $\begin{array}{l}\text { - To acquaint the students with poetry and its types. } \\
\text { - To familiarize them with different aspects of poems. } \\
\text { - To help them explore and enjoy varieties of poems for the } \\
\text { development of language skills and aspects. } \\
\text { - To develop in them critical thinking through the interpretation of } \\
\text { poems from different angles. }\end{array}$ \\
\hline Sixth & $\begin{array}{l}\text { Drama Study } \\
\text { (Eng:365) }\end{array}$ & $\begin{array}{l}\text { - To acquaint the students with introduction, classification and } \\
\text { elements of drama } \\
\text { - To expose them to different dramas. } \\
\text { - To enable students to perform drama in stage. }\end{array}$ \\
\hline
\end{tabular}

Source: Bachelor in English Education Course, Mid-Western University 2013 


\section{Role of the Literature in ELT Course of Mid-Western University}

The poetry, drama, novel, and short stories are prescribed in the course to make students familiar with fundamental elements of respective literary genres. It has also aimed to make students able in language proficiency and teaching different genres of literature. The course of poetry is designed with a view to orient the students with poetry for developing their linguistic competence and critical thinking through it. The course of drama intends to expose the students to a wide variety of dramas to help them to take pleasure from reading as well as develop the skill of literary teaching. The fiction course second semester intends to expose the students to a wide variety of long and short fiction to develop the reading skill of students. The "Creative Writing Seminar" course is designed to develop students' ability and to engage them in creative writing activities and promotion of their English competency. The objectives set in the course of literature contribute to aesthetic, imaginative and intellectual growth of students.

Table No. 3: Literature Related Contents Used in Curriculum

\begin{tabular}{|c|c|c|}
\hline Semester & Course Title & Contents of Course without genres \\
\hline Fourth & Poetry Study & $\begin{array}{l}\text { Classification of poetry (Epic, Lyric, Ballad, Ode, Elegy, Sonnet, } \\
\text { Free verse, Shape poem, slam poetry, haiku, limerick, etc.) } \\
\text { Poetry and prose, Poetry and morality, Poetry and fiction Form versus } \\
\text { content, Form as transcending content, Poetry and performance, How } \\
\text { to read a poem?, Is criticism just subjective?, Meaning and subjecti.. } \\
\text { vity, Tone, mood and pitch, Intensity and pace, Texture, Syntax, } \\
\text { grammar and punctuation, Ambiguity, Rhyme, Rhythm and meter, } \\
\text { Imagery }\end{array}$ \\
\hline Fourth & $\begin{array}{l}\text { Creative } \\
\text { Writing } \\
\text { Seminar }\end{array}$ & $\begin{array}{l}\text { Creative writing: Introduction: What's Creative writing, Why } \\
\text { Creative writing, Literature and language teaching } \\
\text { Poetry: Rhyme, Rhythm and Meter, Figurative Language , Form } \\
\text { poetry, Free verse, Poetry for language development, Practical works } \\
\text { Fiction: Components of short story, Development of short story, } \\
\text { Finishing of short story, Story for language development }\end{array}$ \\
\hline Sixth & Drama Study & $\begin{array}{l}\text { Drama: An Introduction } \\
\text { Genres of Drama: Tragedy, Comedy, Romantic Comedy, Satiric } \\
\text { Comedy, The Comedy of Manners, Farce, Comedy of Humours, } \\
\text { Tragicomedy, Problem Plays, Heroic Plays. Elements of Drama: } \\
\text { Plot, characterization, setting, dialogue, music, movement, theme, } \\
\text { Popular Forms of Drama: One act plays, Three -act play, Five act } \\
\text { plays }\end{array}$ \\
\hline Second & Fictions Study & $\begin{array}{l}\text { Types of Fiction } \\
\text { Elements of Fiction: Plot, Character, Setting, Point of view, Style and } \\
\text { voice, Symbolism and allegory and Theme }\end{array}$ \\
\hline
\end{tabular}

Source: Bachelor in English Education Course, Mid-Western University, 2013

The literature is used there as the content to know the fact about their historical and cultural background as well as the aesthetic value of them. Beside the generic study of literature, it has also prescribed the elements and classification of the genres of literature i.e. 
poetry, drama, novel and short fictions. It has attempted to make students familiar with the nature of respective genres. The aforementioned table shows the contents used in the literature course.

Among language educators, there has been a hot debate as to how, when, where, and why literature should be incorporated in ESL/EFL curriculum (Murat Hişmanoğlu, 2005). Vigorous discussion of how literature and ESL / EFL instruction can work together and interact for the benefit of students and teachers has lead to the flourishment of interesting ideas, learning, and improved instruction for all. Many teachers consider the use of literature in language teaching as an interesting and worthy concern (Sage, 1987, p.1)

As Widdowson (1983) and Carter (1991) have pointed out, there are 'literary ' elements in non-literary texts. There is metaphor in everyday language; the patterns of sound in poetry are also present in songs, nursery rhymes and adverts. (Some) jokes have the 'semantic density' of literary texts, while 'literary' vocabulary and syntax can be found elsewhere too. For Stanley Fish, the American critic, a literary text is simply one we choose to call literary. It is an arbitrary classification for what gets taught in 'literature' classes. It may be more helpful to think in terms of a continuum of literariness. No texts have used literature features equally. (Falvey \& Kennedy, 2006). Until the 1980s, it was received wisdom that literature had no place in the teaching of English as a foreign language. It was thought that linguistic and literature is two separate subjects, and there is no relationship between them in term of learning language in ELT classroom. Therefore, the ELT curriculum of Higher Education of Nepal had not included literature course. However, the situation has changed. The distance, which was created, has been reduced. Now, in textbooks and on language syllabuses worldwide, literary texts are beginning to appear alongside other texts. The change is finding its way into public examinations as well. The literary texts have also placed in the syllabus of linguistic classroom, and the study of language is also included in the syllabus of literature. The current practices of universities of Nepal have changed the old scenario of English teaching programs. Language Arts is no longer marginalized in the English language classroom. The old distinctions between the language and the literature syllabuses are beginning to break down.

The 1980s saw a preoccupation with technique in English Language Teaching (ELT) in methods such as the 'communicative ' method, and the 'Silent Way'. More recently, the importance of content has come to be recognized. Selecting interesting texts to be read for disinterested pleasure may arouse suspicion in a wealth-producing economy, but such texts have an essential role to play in effective language learning. This holds true for texts that have greater depth and are worth reading for their own sake. According to Collie and Slater (1990, p.3), there are four main reasons which lead a language teacher to use literature in the classroom. These are valuable authentic material, cultural enrichment, language enrichment and personal involvement. In addition to these four main reasons, universality, non-triviality, personal relevance, variety, interest, economy and suggestive power and ambiguity are some 


\section{Role of the Literature in ELT Course of Mid-Western University}

other factors requiring the use of literature as a powerful resource in the classroom context (Cited in Murat Hişmanoğlu, 2005).

The ELT practitioners thought that the language of literature is not exactly appropriate for language teaching because it is idealized and figurative. They only focused on significance of linguistic norms which creates the proficiency in the language and important for language teaching. Their concern was in the linguistic norms and values. Moreover, they never thought the value of literature for teaching language. Its significant to provide the real situation how people can communicate the idea, was ignored. It was not realized that literary texts are also made with the certain structure of linguistic phenomena that is supportive for teaching language. This idea was introduced by scholars in designing of syllabus of language teaching classroom. The linguistic became like a hard rock with its own certain structure and values. The curriculum of our subject made us rigid in our area.

The tendency of teaching language has been changed with the passage of time. The literature is no more untouchable in a language classroom. The curriculum of language teaching has selected some of the literary texts in English language classroom. Some of the texts of linguistic and literature have mismatched with each other; the curriculum of both subjects has merged. The time has changed; new generation has known this reality better than the past. Now the curriculum of ELT has used literature into the English language-learning classroom. The usefulness of the style of language used in literary texts has been focused on the English language-teaching classroom. The teachers and students are familiar with language and literature in their classroom either it is literature or language teaching classroom.

My experience teaching English to college's students also reveals that literary texts are fruitful for teaching English language. Works of literature are studied worldwide, mostly for pleasure. However, for last couple of decades, it realized that literary texts are playing significant role in language teaching and are considered great source of authentic materials. Literary texts have become the most important source of English language teaching classroom. Now the literary texts are also incorporated in their syllabus of language teaching program as they offer valuable authentic sources. In this regard, Collie and Slater (2009, pp.3-4) mention that literature is used in language class because it is valuable authentic material; it enhances cultural and language enrichment, and it fosters personal involvement. So, it can be said that literature is an important source in language teaching because it offers varieties of texts along with culture aligned to it, that are useful in language teaching. Similarly, other genres of literature can be useful in language teaching classroom. A poet composes a poem with the use of cohesion and coherence, which can be used in the texture of the linguistic analysis. The devices of language such as simile, metaphor, metonymy, pun, etc are used in the poem, which can be useful tools to study of language teaching classroom. The demonstration and recitation of extract of beautiful verse of poem can create interest and build up comprehension about the language of poetry among the learners. They can create interest and develop comprehension 
about the concept of given in the extract. Therefore, the B.Ed. English curriculum has included 134 poems to create and develop comprehension about the poetic language.

Short stories are also very useful to the English language learners as they are interesting, motivating, and amazing. In this regard, Wright (2000) mentions that making and responding to stories is only way of being creative. Stories offer new language, making it meaningful and memorable, which is a distinctive manifestation of cultural values and perceptions. It requires reflection on values and culture. He further argues that making and telling stories require the students to organize information into cohesive and coherent whole in order to communicate to other people. He also mentions that listening to the stories can develop listening skills whereas studying and learning stories contextualize language diversity in dialect and register of language, and narrative and description of speech. Therefore, 22 short stories of B.Ed. course are useful to learn the four basic skills of language; listening, speaking, reading, and writing. They are also equally helpful to learn grammar, vocabulary and language functions. They promote the imaginative skills and creativity as well through the fun and creative activities of classroom. Teaching stories in the language-learning classroom, engage the more learners with the funny and creative activities. The elements of short stories can be guidelines for creative writing. The learners can write their own stories using those elements.

Similarly, 7 English plays prescribed in the B.Ed course can be useful to promote the language skills of learners. Those plays are composed with use of contextual dialogue in a certain setting of it. The learner knows the contextual meaning of language after reading the play. Therefore, it is beneficial to learn the pragmatic and semantic meaning of the sentences used in the play because the dialogues are used in the conversation among the characters in the certain setting. The play is a representational art of literature, and it has a theatrical performance. The students can involve in the theatrical performance of the play. They can performance the actions and events of the play by using the dialogues. They can promote their speaking skill through the theatrical performance of play and achieve the self-confidence in speaking English in front of the audience. They can develop their presentation skills and develop an understanding of cultural practices of other people through the play. They can be aware about the body language and contextual use of language. Therefore, these prescribed plays in the course develop their language skills watching and listening plays in the classroom.

\section{Conclusion}

In conclusion, the role of literature in the ELT classroom has been reassessed. Now, English teachers and ELT practitioners view that literary texts provide rich linguistic input and effective stimuli for students to express themselves and a potential source of learner motivation. Those literary texts also provide an opportunity for multi-sensorial classroom experiences and can appeal to learners with different learning style. The students can develop their creativity in writing poetry, dialogues and descriptive writing after reading the masterpieces of literary 


\section{Role of the Literature in ELT Course of Mid-Western University}

texts. Likewise literary texts engage to learners how to use figurative language, such as metaphor, metonymy, simile, pun, alliteration, assonance, hyperbole, etc. The literary texts make aware to the learners about the pattern of sounds in language such as rhyme, rhythm, and repetition. Therefore, English language teachers and facilitators can use the literary texts for reading, performance, discussion, creativity-writing activities as authentic sources of language teaching classroom. Considering the reality of developing language, creativity and aesthetic value of literary texts, the B.Ed. English curriculum has introduced the literature course.

\section{References}

Carter, R., \& Long, M. N. (1991). Teaching Literature. London : Longman .

Collie, J., \& S. Slater. (1990). Literature in the Language Classroom: A Resource Book of Ideas and Activities. Cambridge: CUP.

Edmonson, W. (1997). The role of literature in foreign language learning and teaching: some valid assumptions and invalid arguments. AILA Review, 12.

Faculty of Education. (2013). Bachelor's degree in English Education a course of study. Surkhet: Faculty of Education, MU

Falvey P., \& Kennedy, P. (2006). Learning language through literature: a sourcebook for teachers of english in Hong Kong. Hong Kong: HongKong University Press.

Fish, S. (1980). Is There a Text in This Class? The Authority of Interpretive Communities. Harvard: Harvard University Press.

Johnson, P. (1981). Effects on reading comprehension of language complexity and cultural background of a text. TESOL Quarterly, Vol.10 (2), pp.221-239.

Marsh, C. J., \& Willis, G. (1999). Curriculum: Alternative approaches ongoing issues. New Jessy: Prentic-Hall.

Murat, H. (2005). Teaching English Through Literature. Journal of Language and Linguistic Studies Vol.1, No.1. Retrieved from http://www.jlls.org/index.php/jlls/article/ viewFile/6/7 on 23 January 2018

Richards C. J., \& Schmidt, R. (2002). Longman dictionary of language teaching and applied linguistic $\left(4^{\text {th }}\right)$. London: Pearson Education Limited.

Sage, H. (1987). Incorporating literature in ESL instruction. New Jersey: Prentice-Hall, Inc.

Tehan, P., Yuksel, D., \& Inan, B. (2015). The Place of Literature in an English Language Teaching Program: What Do Students Think About It? The Reading Matrix: An International Online Journal Vol. 15. No. 2 pp.1-8. Retrieved from https://www. researchgate.net/publication/ on 15 Dec. 2017.

Widdowson, H. G. (1983). Talking shop: literature and ELT. English Language Teaching Journal Vol. 37 No. 1: pp.30-36 .

Wright, P. (2011). Stories and their importance in language teaching. I--n humanizing Language Teaching, Year 2; Issue 5.

Yuksel, D. (2007). The nature of discussions in an advanced-level literature course in a Turkish EFL setting (Unpublished doctoral dissertation). Tallahassee: Florida State University. 